\title{
社会政策:少子高龆化のアジアと EU比較
}

猪口邦子

\section{1．基層的変化}

人口の推移は経済や社会の長期的趨勢や課 題を規定する根本要素の一つである。世界人口 は20世紀後半から急増し、1900年には 16.5 億 人、 1950 年には 25.4 億人、 1990 年には 50 億人 に達し、2000年には60億人をこえ、2007年に は66.7億人となった。他方で人口増加率は鈍化 の傾向に入り、また地域的差異が顕著となって いる。地域別に合計特殊出生率を見ると、アフ リカが4.67 と高いのに対し、アジアは2.34、ヨー ロッパは1.45であり、とりわけOECDの東アジ ア国である日本と韓国は、それぞれ 1.34 と 1.13 という急激な少子化現象に陥っている。

急増期の人口の高齢化と、続く現役世代の少 子化傾向による人口変動は、欧州とアジアの両 地域に共通の政策課題をもたらし、その緊要性 は、両地域の対応力の差異を顕在化させること になった。また、欧州とアジアには、EU（欧 州連合）や東アジア共同体等、経済政策では参 加国の内政に強い作用のある地域的枠組みや ネットワークがあるが、家族政策、少子化対策、 高齢化問題など媣く人間社会に係る社会政策 においては、国民国家単位の独自色の強い政策 の試行錯誤が続きやすい傾向も明らかになり つつある。他方で、人口推移の過剩という静か なる基層的変化への危機感から、家族政策や少 子化対策に関する行政交流や政策対話がそれ ぞれの地域内にても、また欧州とアジアの間で
も進み始めている。11

\section{2. ポスト冷戦期におけるEUと 東アジアの少子化現象の差異}

1960年代までは、欧州諸国や日本・韓国の 合計特殊出生率は 2.00 以上であったが、1980年 代前後から全般的な低下傾向を示すようにな る。1960年から 1995 年への推移を見ると、例

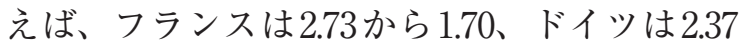
から 1.25、英国は2.72から 1.71、スウェーデン は2.20から 1.73、韓国は5.63から 1.70、日本も 2.00 から $1.42 て ゙ あ る 。{ }^{2)}$ この傾向が示唆する、 社会政策の不足や性別役割分業等に基づく経 済発展の矛盾についての認識の密度や対策の 差は、その後の各国の合計特殊出生率の差異に 直結することになる。

1990年代には、先進各国の予算配分に稀な 根本的変化をもたらし得る大規模な国際政治 経済関係の変容、すなわち東西冷戦の終結と経 済のグローバル化現象があった。

両ドイツの統一やソ連邦解体による東西冷 戦の終結は、平和の配当の余地を生み出し、核 軍拡時代には後回しにされがちであった社会 保障分野への分配強化や社会政策の優先順位 の向上を可能にした。また1980年代前半の第 二次冷戦期には、欧州戦場を想定する中距離核 ミサイル（INF）の配備が決行された欧州では、 若年世代を中心に広範かつ浸透力の強い反核 運動が広がったが、冷戦終結時に初の核軍縮条 
約であるINF全廃条約が成立して核問題が相 対化すると、冷戦型の市民運動は部分的に、環 境、人権、平等など内政の社会発展関連の政策 要求ネットワークへと変容ないし再編成され、 冷戦後欧州における女性や若年層を含む積極 的な市民社会（civil society）運動の素地となっ た。そして男女平等政策や保育・教育政策など 若年就労層の関心領域への市民的圧力は、ポス 卜冷戦期の EU諸国がすばやくそのような社会 政策分野の重点化へと舵を切り、関連施策を推 進する政治力にもつながった。この時期には平 等政策や家族支援政策を重視する議会人が女 性も含め国政にも地方議会にも急増した。

さらに冷戦終結により民需に開放されやす くなった高速通信情報システムや技術は、市場 のグローバル化をもたらすが、その新たな経済 機会と向き合うための規制緩和や競争促進の 政策体系が推進されるなかで、必然的にセイフ ティーネットを整備し、労働環境の劣化を防ぎ、 家族・生活者・再生産者の権利擁護を実質化す る社会政策への圧力も強まった。

このような大局的な変化を背景に、大半の $\mathrm{EU}$ 諸国では1990年代から少子化対策や男女平 等政策を抜本的に強化し、ワークライフバラン ス型の社会構築や保育・教育サービスの拡充が 進み、女性の労働力率の向上と合計特殊出生率 の向上の相関を経験するようになる。軍拡と 冷戦の国際構造を遠景とした男性中心の社会 組織原理が目立った時代には、EU諸国でも仕

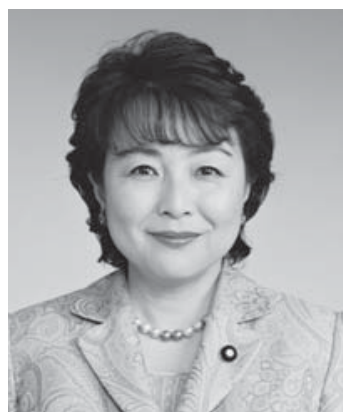

\section{PROFILE}

猪口邦子

(いのぐち くにこ)

日本学術会議第一部会員、衆議院議

員、エール大学大学院政治学博士号

(Ph.D.) 取得、元ジュネーブ軍縮会

議日本政府代表部特命全権大使

専門：政治学

事と家庭の両立の困難性のなかで女性の合計 特殊出生率が低迷したが、ポスト冷戦期には男 女平等型社会原理や家族支援政策の追求と軌 を一にするかのように合計特殊出生率が回復 した。フランスは1.98へ、ドイツは $1.45 へ 、$ 英 国は1.84へ、スウェーデンは1.85へと、上記の 1995年から 10年余りの間に欧州 OECD諸国は 回復基調を実現した。現在では北欧諸国と英仏 が1.8から 1.9 台の高い回復水準に至り、1.3か ら 1.4 台の相対的低水準にあるのはドイツ、イ タリア、スペイン、ギリシャだが、そのいずれ もが、1990年代半ばからは回復している。 ${ }^{3)}$

他方で、東アジアの結果は大きく異なる。ま ず冷戦終結はアジアでは大幅に遅れ、よって平 和の配当や軍拡から社会政策への重点化シフ トは鮮明になりにくいまま、2001年9.11アルカ イダ同時多発テロ後の時代となり、ポスト冷戦 期のつかの間の内政重視の機会を逸した観が ある。国際変動は大西洋社会にて生起し、遅れ て、さらに激化してアジアに到達するという近 現代世界で頻繁に観察された構図は、冷戦終結 の局面においてさえも反復され、アジアの社会 発展の遅れの遠因を成した。 
そのような国際政治環境の違いがあるとはい え、主要先進国日本の場合、グローバリゼイショ ンの潮流のなかでの経済のバブルとその崩壊 という 1990年代の姿は、社会政策の拡充に分 配し得たはずの国富や民間の余力を、野心的な 社会政策の企画立案の不足や行政的惰性から 旧来型の使途にバブリーに費やしたことを思 わせる。同時期の EU主要国と比べると女性や 子どものための社会政策重視への行政や政治 の転換期の舵取りが緩慢であり、少子化対策や ワークライフバランス推進の遅れは、EU諸国 では女性の労働力率も合計特殊出生率も向上 した1990年代を通じて、日本の女性たちには 仕事か家庭かの苛酷な選択を迫ることにつな がった。年功序列の伝統的慣行を維持したまま のグローバル化競争による若年世代の経済的行 き詰まり感も絡み、未婚化、晚婚化、家庭を選 択した主婦層の疎外感と少産化という、欧州と は異なる 21 世紀初頭の社会的現実が見られる。

日本の合計特殊出生率は2005年に 1.26 と過 去最低となり、同年には初の専任の少子化担当 大臣を設置しての取組みを余儀なくされた。4) 2006 年には 40 年余ぶりの上昇幅（0.06）の 1.32 となり、2007年にも 1.34 と 2 年連続の上昇とは なったが、EU主要国の回復ぶりには遥か及ば ない。もし 1970年代前半の第二次べビブーム 世代が 20 代であった 1990 年代に、抜本的な男 女共同参画 - 少子化対策重視の分水嶺を築いて いたなら欧州並みの回復も視野に入ったかも しれない。出生数は2006年には109万台に回復
したが、2007年には 108 万 9745 人へと減少し た。出生数から死亡数を引いた自然増加数は、 2006年には一旦増加に転じたが、2007年には1 万 8535 人減で再びマイナスとなった。

東アジアの他の国家・地域も欧州とは大き く異なる傾向を呈している。 ${ }^{5 ）}$ 韓国では、日本 と同様 1990 年代を通じて合計特殊出生率は低 下し続け、2005年には1.13となり、シンガポー ルでも1960年の4.93から1990年代には1.70、 2005年には1.25、台湾においても 1960年の 6.59

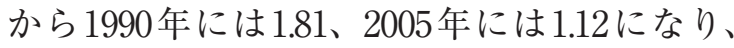
いずれにても日本より低い。中国は1979年か らの計画生育政策、いわゆる一人っ子政策の結 果、1960年の 3.41 から 2005 年には 1.70 となっ た。タイは1960年の6.39から 1990 年には2.00、 2005年には 1.83 に低下した。合計特殊出生率が 人口置換水準の 2.1 を現在も上回るインドネシ ア、マレーシア、フィリッピン等においては、 1960 年代の 6.00 ～ 5.00 台から 1990 年代には 2.00 〜 4.00台へと低下し、2005年にはインドネシ

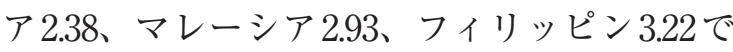
ある。

東アジア諸国のなかでも、平均寿命の低さに 集約される貧困と所得不平等を含む低発展問 題に病んでいた途上国の合計特殊出生率の低 下は、経済成長と平均寿命の向上により多産多 死の不安感から脱却した結果の少子化であり、 先進国であるにもかかわらず男女平等政策や 保育支援等の社会政策が遅れた結果の少子化 とは異なる。1950年における平均寿命はイン 
ドネシア 37.5 歳、マレーシア 48.5 歳、フィリッ ピン 47.8歳であり、この諸国における1950年 から 2005 年の期間の平均寿命の延びは、日本 が18歳（63.9歳から 81.9 歳）であるのに対し、 インドネシアは 31 歳、マレーシアは 25 歳、フィ リッピンは 23 歳もの伸びである。このような 諸国の少子化 $=$ 合計特殊出生率の人口置換水 準への接近は、まさに乳幼児死亡率低下や栄養 失調人口の減少など絶対的貧困がもたらす短 命化を克服した安心感や、農村等の児童労働関 連の多産的風土が経済成長により近代化され たことによる。

すなわち東アジアには経済政策の成功から 少子化になる諸国と、社会政策の失敗から少子 化になる諸国が混在するが、前者においては、 経済成長に安住してその果実を浪費したりせ ず、間断なく社会発展に取組む必要がある。そ の政策的イニシアティブが遅れると後者の事 例に陥ることになろう。日本も長い時間軸で見 ればそのような事例であろう。日本にも貧困か らの脱却の成果として家族計画と少子化が進 む歴史の段階があったが、その後も出産育児期 の家族支援や男女平等政策の取り組みは先鋭 化されず、経済は世界 2 位の規模で、国民所得 も世界18位でありながら、家族政策向け政府 支出ではOECDの全EU諸国より下位にあり、 また男女平等指数の国際順位は 54 位というア ンバランスな社会になり、吕 世界で最も急激な 少子高齢化を遂げる国となった。

韓国の場合、平均寿命は 1950 年の 47.8 歳か
ら 2005 年には 77 歳へと、30歳も延びた。よっ て韓国の少子化はその経済成長と近代化の成 功がもたらした面はあるが、他方で冷戦後の韓 国の著しい経済発展は相応の社会政策重視を もたらしたわけではなく、日本の未婚化、晚 婚化、子育て主婦の疎外感等と似通った困難を 韓国も経験している。他方で韓国では女性就業 者のうちフルタイム労働者の割合が $\mathrm{OECD}$ 諸 国中最も高いため（日本は最下位から 3 番目）、 保育支援ニーズは強く、政策的にも重点化が進 みつつあるが、まだひずみは大きく、合計特殊 出生率は日本より劇的に低下したままである。 韓国 20 代後半男性の未婚率は $71 \%$ で、日本よ り高い。20代後半の女性は日本で 5 割、韓国で 4 割が未婚である。OECD諸国のなかの日韓共 通の課題は男女平等政策の遅れである。欧州で は EU指令により男女同一賃金原則が定められ たこともあり、フルタイム労働者の男女間賃金 格差は 1 ～2割程度だが、OECD諸国のうち男 女間賃金格差の最大国は韓国 (4割)、次いで 日本（3割）であり、欧州と東アジアの違いが 顕著である。女性の労働力率も OECD諸国の なかで東アジア2力国は最も低いグループに入 り、韓国より低い国はイタリアのみである。7)

シンガポールの場合は、平均寿命はすでに 1950年に 60.4 歳と高く、その後の伸びも日本と ほぼ同様である。合計特殊出生率のとりわけ 2000 年代に入ってからの急落は、子育て支援 や男女平等政策の不足や遅れが、経済発展段階 に不釣合いなものになり、その矛盾が未婚化、 
晚産化、少子化へとつながったと思われる。 ${ }^{8)}$

\section{21 世紀の欧州とアジアの 少子化対策}

EU諸国が合計特殊出生率の回復を実現した 背景には、経済的支援と保育サービスや育児休 業制度の充実がある。それにより女性の労働力 率が高まり、働く女性の増大は保育や子育て支 援強化への圧力を一層高め、よって家族支援 策がさらに進んで子どもを生み育てやすい社 会環境が深まるという好循環が見られる。家族 政策向けの政府支出には、児童手当や育児休業 手当などが含まれるが、そのGDP比をみると、 たとえば合計特殊出生率が1980年の 1.55 から 2005 年には 1.80 に回復したデンマークや、 1.68 から $1.85 に$ 回復したスウェーデンは $4 \% 、 3.5 \%$ であり、日本は $0.8 \%$ 、韓国はさらに低く、 EU 諸国とは明確な差異がある。英仏も北欧諸国と 並んで3\%前後を維持している。GDP 比 $3 \%$ と は、かつて戦後復興時の米国から欧州への大 規模援助マーシャルプランの比率であり、 $\mathrm{EU}$ 諸国は女性や家族という戦後経済発展の犠牲 となった内なる同盟地帯にまさに内なるマー シャルプランを思わせる支援を政策的決意に より実行し、趨勢が回復する結果を得ている。 経済規模が日本に次ぐドイッでも GDP 比約 $2 \%$ を投入し、1995年には日本さえ陥ったことの

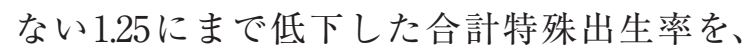
2007 年には現在の日本をはるかに超える $1.45 に$
まで回復させた。東アジア先進 2 力国の少子化 対策における経済支援の遅れは鮮明である。

日本では筆者の担当した「新しい少子化対策」 （2006年 6 月政府決定）で児童手当における乳 幼児加算を創設し、初めて乳幼児に着目した経 済支援（3歳未満児一人月一万円）を導入した ほか、育児休業給付を 4 割から 5 割に引き上げ る等の経済支援重視に舵を切ったが、今後の抜 本的な強化が必要なことは EU諸国との比較で も明らかである。韓国は日本の経験を研究しな がら児童手当制導入の検討に入っている。

各国の少子化対策の経済支援の詳細は別途 の資料に譲るが、9) 代表的な事例を付しておき たい。少子化対策は総合的かつ多角的である必 要があるが、大別すると経済支援と保育支援が あり、さら大局的には長時間労働克服や職住接 近などすべての就労者のためのワークライフバ ランス推進も少子化対策に資するものである。 少子化問題が先鋭化している局面では迂遠的な 手法より、直接に出産育児期の家族を支援する 具体的な給付、サービス、制度が重要である。

経済的支援の手厚さで傑出するのはフラン スである。家族手当という基本となる児童手当 は第 2 子以降の 20 歳未満の児童を対象に支給さ れる養育費補助として設計されているほか、30 種類もの手当てがある。乳幼児迎入れ手当てや 出産先行手当て、新学期ごとに子ども 1 人につ き約 3 万円も給付される新学期手当て、 3 歳以 上の児童を 3 人以上扶養していれば 3 人目以降 に 1 人に月 2 万円の家族補足手当等。家族給付 
の財源は企業からの拠出金が 6 割を占める公庫 が担っているが、税制において $\mathrm{N}$ 分 $\mathrm{N}$ 乗方式を 実施し、累進税率が高い場合、家族の数が多い ほど所得税が緩和される。保育需要面では在宅 での保育サービスが認定保育ママ制度など発 達している。一定の要件を備えた者を登録する 制度で、 34 万人の登録があり、25万人が就業し、 保育需要の 7 割を担っているという。

スウェーデンは高い育児休業取得率に特徵 がある。1974年に導入された両親保険と呼ば れる制度は世界でも初めての両親を対象とす る出産・育児・看護休暇で、子どもが8歳にな るまで1人につき 480 日分の所得が保障され、 父親に割り当てられるパパ・クォータも含まれ る。取得率は男女共に8割で、さらに子どもが 8歳になるまでは勤務時間短縮を雇用主に請求 する権利もある。かつてスウェーデンでは、世 界恐慌の影響下で出生率が1.7に落ち込んだこ とに対してミュルダール夫妻の『人口問題の危 機』（1934年）は、出生率低下は労働力低下に つながるので、女性も働いて子育てできる社会 の建設を求めたが、少子化対策には社会思想と 政策設計力が必要であることを示している。

デンマークでは、子どもが9歳になるまでの 間に所得の $90 \%$ が保障される育児休暇を両親 合わせて 32 週間取得できる。日本では育览休 業の時期分割には特別の事情が必要だが、北欧 では分割可能型が主流である。子ども看護休 㗇は所得 $60 \%$ で子どもが 14 歳まで取得可能で あり、重病の子どもの世話のためには 18 ヶ月
中 52 週間分取得可能。日本では就学前の子ど もをもつ親 1 人につき、年 5 日までである。ス ウェーデンでも子どもが 12 歳になるまで子ど も1人につき各親 60 日の看護休㗇が所得 $80 \%$ 保障で可能である。

ドイッでは 3 歳までは家庭保育の観念が強く 保育サービスの発達は遅れたが、育児休業が 3 歳まで利用できる。また家庭保育重視の観点か らも児童手当が手厚く、18歳未満の子どもに つき 2 万円強の給付があり、税制面では手当て と選択制で、子ども 1 人につき年額 78 万円相当 を控除可能で、所得が高い人ほど控除を選択す るようになっている。また最近では経済支援 を超える総合的政策を展開し、2005年には保 育所設置促進法の実施により保育所整備の促 進を図り、2006年には育児休業促進のために、 最長 3 年まで分割しても取得できる両親手当て を創設した。出生率は一時は日本より低い水準 から、昨年は日本を遥かに超える 1.45 へと反転 した。

\section{4. むすびに代えて}

日本、韓国、シンガポールなど急速な少子化 に直面する東アジア諸国は、EUの経験を研究 し、多様性と工夫と試行錯誤に満ちたその努力 を比較し、参考にしょうとしている。EUとい う地域統合の枠組みがあるにもかかわらず、家 族と子育てのような社会の深部に係る政策分 野については国民単位の制度や政策が林立し、 
互いに参考にしつつも、一元化を求めたり統合 しようとする動きは目立たず、国民の再生産と いう基層において近代国民国家の主権性の奥 まった砦を垣間見るようでもある。

主権国家論において、防衛政策と通貨政策は 主権の両輪であると、かつてよく言われた。地 域統合の先駆者 EUで、共通通貨が導入され、 外交・防衛においても共通政策やポジッション が形成されていく現代においても、いまなお、 国民的で独自性の強い家族政策と子育て支援 は百家争鳴のごとく加盟各国で多大な情熱と 予算を投入して展開されている。主権とは、な によりもまず主権者の再生産であり、主権者の 養育であり、主権者を育む家族と共同体の暗黙 知の世代間共有であることを、近代主権国家の 歴史の外縁に位置した女性たちが、いままさに 主権者として明らかにしようとしているかの ように、EU諸国の家族政策は多様な主張と希 望を帯びている。思えば近代国家と主権概念は ヨーロッパ政治思想に始まるが、世界に先んじ て自国らしい家族・子育て支援の政策構築を目 指す欧州各国は、そこにこそ永久主権の仕掛け を直感しているのかもしれない。少子化対策が 遅れることは、主権を担い、主権国家を構成す る主権者の縮小や世代的消滅を意味し、そのこ とについて、あせらない東アジアと、あせる欧 州との対比が、主権の深層と向き合う迫力の差 異に、そして出産育児支援をめぐる情念と感受 性の差異に映し出されている。近代世界の中核 を成した主権概念の母なる欧州を、子（=主権
者）育て支援で東アジアが追い越すとき、アジ アはついに近代を超えるのかもしれない。

注

1）例えば、2006年から東アジア男女共同参画担当大臣会合 が始まった：キム・ハクスー「東アジアにおける共通の 特徵」『共同参画21』2006年9月号、10-15. 少子化対 策の日韓政策対話も同年に開始

2) 韓国は1990年の数值

3）内閣府『平成19年度少子化の状況及び少子化への対処 施策の概況（第169回国会 (通常国会）提出)』及び同 平成18年度版。欧洲諸国のワークライフバランスの比 較研究については、EU Expert Group on Gender, Social Inclusion and Employment (EGGSIE) Reconciliation of work and private life: A comparative review of thirty European countries, European Commission, 2005. EUに おける出産休睱取得を理由とする昇進機会差別問題につ いては、柴山恵美子「欧州司法裁判所の判例と2006年 統合・改正「雇用・職業男女機会均等・待遇指令」「賃金 と社会保障』1460号、2008年、28-49頁。

4）增田雅暢『これでいいのか少子化対策：政策過程からみ る今後の課題」2008年、ミネルヴァ書房

5）東アジアの少子高齢化については、大泉啓一郎『老いて ゆくアジア：繁栄の構図が変わるとき』中公新書。小峰 隆夫/日本経济研究所センタ一編『超長期予測：老いる アジア』日本経済新聞出版社、2007年。2007年；みず ほリポート『高齢化する東アジア』2008年8月.

6 ) GEM(Gender Empowerment Measure) : UNDP, Human Development Report 2007. 内閣府『平成19年度男女共 同参画社会の形成の状況 - 平成 20 年度男女共同参画社会 の形成の促進施策』(第169回国会 (通常国会) 提出) 三 菱UFJリサーチ＆コンサルティング調査部『調査と展望』 No.6.

7 ) OCED, Employment Outlook 2007ediion, 2008 edition.. OECD, Stat Extracts, EUrostat. ウンョン・チョイ「韓 国の新たな社会的リスク：仕事と家庭の両立、所得格差」 『海外社会保障研究』163号、2008年、65-79頁。

8）みずほリポート『高齢化する東アジア』2008年8月.

9 ) 内閣府『少子化社会白書』平成 17 年度、18年度版。阿 藤誠編「(特集：子育て支援策をめぐる諸外国の現状) 『海外社会保障研究』160号、2007年、2-129頁。萩 原康生他編『世界の社会福祉年鑑2007』(旬報社)。 Sleebos, J.E., Low fertility rates in OECD countries: facts and policy responses, Paris: OECD; EU Expert Group on Gender, 2007 op.cit. 